Journal of Strategic Management

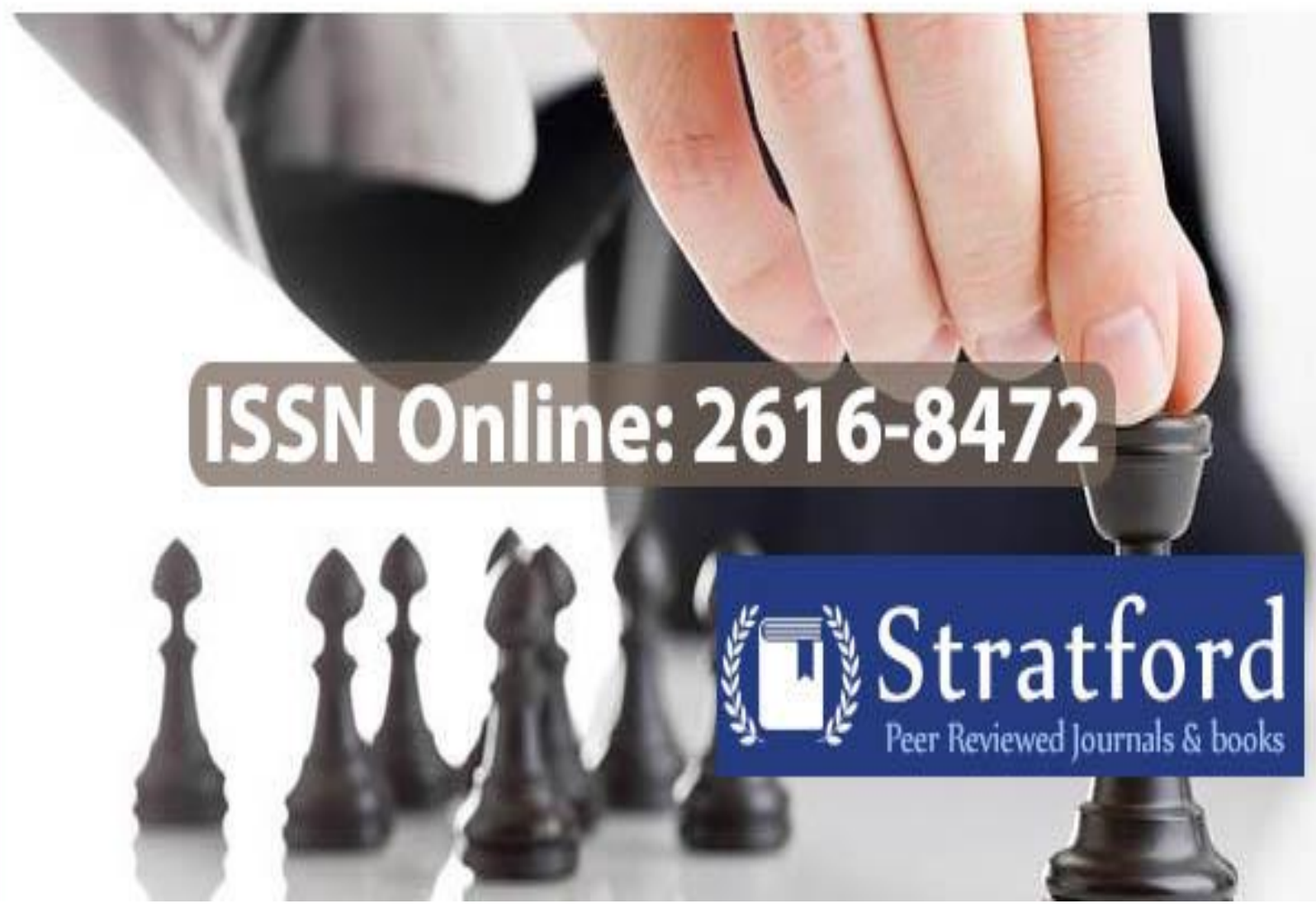

Strategic Analysis of Opportunities and Risks for New Zealand Drug Firms

Ruby Amelia \& Noah Isla

ISSN NO: 2616-8472 


\title{
Strategic Analysis of Opportunities and Risks for New Zealand Drug Firms
}

\author{
${ }^{* 1}$ Ruby Amelia, The University of Auckland, New Zealand \\ ${ }^{2}$ Noah Isla, The University of Auckland, New Zealand \\ *E-mail of corresponding author: ameliar@gmail.com
}

How to cite this article: Amelia R \& Isla N (2022): Strategic Analysis of Opportunities and Risks for New Zealand Drug Firms. Journal of Strategic Management. Vol 6(2) pp. 25-31. https://doi.org/10.53819/81018102t2048

\section{Abstract}

Firms have ambitions that they will grow and become a global entity with high returns. Several New Zealand companies such as Merck \& Co., Novartis and Roche have been successful whereas others have tried and not succeeded for different reasons. There are usually several factors to put under consideration and many crossroads on the road to success of becoming a profitable multinational company. Whichever way a company decides to follow, clear strategies are usually paramount. This paper presents a comparative analysis of the opportunities and risks of expanding to either China or Africa. The paper an analysis the opportunities and risks that New Zealand drug firms looks into in its aspiration to expand its market base after sales recorded indicated a stall. For sustainability, New Zealand drug firms looks into expanding its products to either China or Africa, which are foreign markets. The paper further outlines on the factors that favor market entry into the foreign market and makes a justification for the preferred choice.

Keywords: Market Share Analysis, Opportunities and Risks, China, Africa \& New Zealand Drug firms.

\subsection{Introduction}

Companies have the dreams that one day they would grow and become a global entity with high returns. Several New Zealand companies i.e. Amcor, Telstra and Wesfarmers have been successful whereas others have tried and not succeeded for different reasons. There are usually several factors to put under consideration and many crossroads on the road to success of becoming a profitable multinational company. Whichever way a company decides to follow, clear strategies are usually paramount. This report will do a comparative analysis of the opportunities and risks of expanding to either China or Africa. The report looks into the economic political financial and cultural risks and opportunities for both countries so to ascertain the best preferred for expanding the pharmaceutical market. 


\subsection{Analysis of Risks and Opportunities}

\subsubsection{China}

\section{Economic}

The large work force and large market potential in China has made its market attractive for business. The country is ranked as the second largest economy globally although still under a developing country category (World Bank Group 2017). Going by manufacturing and trading output, China leads globally. The economic growth rate has been stable and projected to remain between 6.7 and 6.8 by 2019 . However, there is high inequality rates having been fostered by rapid urbanization and low per capital income ranks for the last two decades (Lu 2018). Inflation rate in China is relatively low with not more than $3 \%$ for years as compared to other emerging countries. The projected inflation rate is shown in Figure 2. China is also New Zealand largest source of imports; The New Zealand Government has been taking forward a major new 'sector by sector and province by province' trade initiative with China. Again, New Zealand has been working closely with China to conclude the WTO Doha Development Agenda that will further enhance mutual trade.

In China, there is a market population of 1.36 billion people, which is about 56 times of New Zealand population. The government one-child policy was terminated in 2013 in order to prevent an ageing population. Demand for healthcare and drugs is projected to rise as a consequence of the aging population as the elderly population usually have weaker immunity in their bodies and thus high chances of getting ill. Currently, the senior population sums up 23 to $40 \%$ of the drug prescription and about 40-50\% of over the counter drugs (OTC) (Li, \& Lyu, 2018). A key driver to the need for pharmaceutical expansion is the rising awareness in healthcare and the needs that are exerted by the economic growth, the increase in total and per capital health spending, large and ageing population as shown in Figure 3. More than 300million people are in the middle class owing to the soaring household incomes. By 2030, the urban middle class is projected to be at 70 per cent of the total population (Ekelund \& Persson, 2017).

In China, generic drugs are the backbone of the pharmaceutical industry in China and is projected to remain so for years. However, the confidence in intellectual property protection is likely to attract many global pharmaceutical players to unearth the demand for patent drug market in China (David, Dorn, Hanson, Pisano \& Shu, 2016). Foreign brands in China attract high confidence and therefore are expected to win the customers pulling them away from the local generic brands and thus causing a proportional share in the market. The pharmaceuticals patent period is 25 years and this provides adequate time for research and development for the drugs and enough time to recover financially after sales of the patented drugs.

The government of China plays a dominant role in controlling the economy and thus present chances of vulnerability of foreign firms. Additionally, the high role in government controls and cyber security hampers smooth establishment of foreign firms in the country (Geng, Tian, Sarkis \& Ulgiati, 2017). In China, foreign companies in pharmaceutical industry are subjected to local trials for their products even if approved by other countries. This has been linked with increased research and development costs and further delay in approvals. According to China's Risk Report (2018), the general rating of economic risk is low. 


\section{Political}

The Chinese communist party has had consolidated power in China since March 2018 as the term limits for the president was lifted. The establishment of the national supervision commission was effected to strengthen party allegiance. However, this has been cited to be a cause of commercial disruptions using political means and increasing operational risks. There have been a lot of politicization in the judicial system and theft in intellectual property has remained as a business risk although the government has shown efforts in curbing it. China is ranked fifth globally in contract enforcement efficiency (Zweig, 2018). Despite the efforts by the current president Xi Jinping to curb corruption, there is still inadequate transparency.

Corruption, pollution, labor disputes, land acquisition have been some of the causes of social unrest in China. However, the impact of the social unrest is usually low given the intolerance for dissent and a strong centralized control by the government. According to China's Risk Report (2018), the general rating of political risk is moderate.

\section{Financial}

The external financial position of China is strong that enables it maintain favorable foreign exchange reserves. Chinas current account has been on a constant surplus. Chinas rapid economic expansion has been significantly driven by credit growth although there are usually shocks originating from excessive lending (World Trade Organization, 2017). Nevertheless, the country has been working to reinforce the supervision and oversight of the financial institutions. The infrastructure in energy, transport and communication is enormous and supports manufacturing. According to China's Risk Report (2018), the general rating of financial system risk is moderate.

China and New Zealand have a free trade agreement entered in 2015 that allows economic relations with New Zealand. The trade agreement unlocks potential opportunities between the two countries where New Zealand biggest exports are goes to China (Brandt \& Morrow 2017). Nonetheless, foreign companies' activities in China are stipulated to be within the specified scope by the local regulating laws. A foreign company must register a legal entity for it to be allowed to hire any employee. Intellectual property protection in China is comprehensive on trade secrets, copyrights, trademarks and patents but the ineffective enforcement of the regulations has led to the occurrence of frequent violations.

\section{Cultural}

In China, a section of the population still adopt traditional medicine known as Traditional Chinese Medicine (TCM). This involves use of herbs and various body and mind practices with the belief that interrelation between the body and the environment brings cure (Farquhar, 2018). This keeps them away from modern medicine. However, the small population that practices TCM in China is embracing modern medicine gradually.

\subsubsection{South Africa}

\section{Economic}

South Africa's economy is diversified with plenty of natural resources for exploitation. According to the best Country Risk Report (2018), the financial and manufacturing sector have underweighted mining and agriculture in overall GDP contribution. The growth rate has been unstable as shown in Figure 4. The unemployment rate is projected to about $25 \%$ although measuring the actual rate has been hindered because of the large informal sector of the economy 
in the country. The inflation rate has been considerably high at 5.2\% in the year 2017 and projected to $5.3 \%$ by the year 2019 shown in figure 5 .

Additionally, the country is one of the most inequitable economy in the world with $40 \%$ of the population living in poverty-less than $\$ 1.75$ for a day. South Africa population is about 55million people with about $25 \%$ in middle class and above. The population structure in South Africa is largely middle aged, poor and independent as shown in Figure 6.

Policy uncertainties in the country have resulted to a lower investment spending and this cautions the ability of both the consumer and investor confidence. There is also a limited ability of the government of South Africa to stimulate the economic growth as result of the fiscal constraints. According to the World Bank index (2017) on ease of doing business, South Africa overall performance has dropped from position 39 in 2013 to position 82 in 2017. This is highly attributed to the poor infrastructure in electricity availability and connectivity (Ravenhill, 2017). However, it is rated ahead of other African countries in ease of doing business. According to South Africa Risk Report (2018, p. 2), the general rating of economic risk is high.

On intellectual property, South Africa is a signatory member of treaties such as Agreement on Trade Related Aspects of Intellectual Property Rights (TRIPS Agreement), World Trade organization (WTO), Paris Convention for the Protection of Industrial Property, Berne Convention for the protection of literacy and artistic works, patent of cooperation treaty and finally the World intellectual property organization (WIPO) (Eze, 2016). Counterfeits are also a concern as they damage the reputation of a brand name. In South Africa, drug patent period is 20 years (Roux, 2016). In general, South Africa has had provided sufficient safeguard on intellectually property rights although there are instances where infringement occurs especially on copyright and trademarks.

According to the World Bank (2014) estimates on healthcare, South Africa stands at $8.9 \%$ of the gross domestic product. The growing middle and upper class in South Africa who are privately insured are usually willing to pay for high standards in medical treatment. Again, the generic drugs market is huge especially in the public sector. Mylan, which is a multinational firm, is the highest pharmaceutical firm in South Africa.

\section{Political}

The political arena in South Africa experienced a change in February 2018 when Jacob Zuma a 9year president was replaced with Cyril Ramaposa as the president. During the Jacob Zuma era, corruption allegations were rampant (Haggard, Stephan \& Robert, 2018). In May 2019, there are scheduled legislative elections where a president will be elected. The rate of government debt have been raising significantly over the las 10 years. Further, the burden of interest rate has also raised owing to the low sovereign ratings. There are high probabilities for economic protests as a result of the labor related and the government inefficiency in availing services to the public in many neighborhoods. According to South Africa Risk Report (2018), the general rating of political risk in South Africa is high.

\section{Financial System}

In April 2018, there was change in the insurance regulation body from Financial Services Board (FSB) to two new boards namely Prudential Authority (PA) and the Financial Sector Conduct Authority (FSCA) that were meant to restore market fiscal credibility. There is a well developed 
capital market that is also the largest stock exchange in Africa and among the top 20 globally. There have been a well-coordinated, capitalized and profitable banking system as a result of pricing power and the limited competition. However there plans to introduce new banks that will enhance competition, increase credit availability and lower user charges. The overall regulation of private limited liability companies in South Africa is the Companies Act. According to South Africa Risk Report (2018), the general rating of financial system risk is moderate.

\subsubsection{Selected Country Destination and Justification}

Given the opportunities and risks for both China and South Africa, China offers better opportunities for expansion of a pharmaceutical company. China's economy has been expanded rapidly unlike that of South Africa that has stagnated as shown in Figure 1 and 4. The economic growth rate has been stable and projected to remain between 6.7 and 6.8 by 2019. In contrast, the economy of South Africa has been unstable as shown in Figure 4. Inflation rate in China is considerably low with not more than 3\% for years as compared to other emerging countries. The inflation rate for South Africa has been beyond 5\%. The country's large work force and large market potential has made its market attractive for business with a market population of 1.36 billion people unlike South Africa that has about 55 million and about half live below the poverty line.

In China, demand for healthcare and drugs is projected to rise as a consequence of the aging population as the elderly population usually have weaker immunity in their bodies and thus high chances of getting ill. More than 300million people are in the middle class owing to the soaring household incomes. By 2030, the urban middle class is projected to be at 70 per cent of the total population. Additionally, foreign brands in China attract high confidence and therefore are expected to win the customers pulling them away from the local generic brands and thus causing a proportional share in the market. The pharmaceuticals patent period is 25 years and this provides adequate time for research and development for the drugs and enough time to recover financially after sales of the patented drugs unlike South Africa, which has 20 years. According to China's Risk Report (2018, p. 2), the general rating of economic risk is low, political risk is moderate and financial system risk is moderate. Further, China and New Zealand have a free trade agreement entered in 2015 that allows economic relations with New Zealand.

Given the opportunities, the entry strategy would be to begin contractual exporting of antibiotics for the ageing population in China and thereafter establish a production firm in China. This is because setting up of a pharmaceutical manufacturing firm in China takes a lengthy period due to the legislation process. The sale of pharmaceuticals can proceed as the company awaits full authorization to manufacture drugs in China. This would also help in overcoming cultural barriers as the contracted companies are domestic and are more informed on the domestic market. The 25 years of drug patent is favorable for research and development thus will allow the company regain profits after sale of the patented drug for period

Therefore, China is a more lucrative market place for the pharmaceutical expansion considering expansion in the production and distribution network. Nevertheless, just like any new business entity, there is need for continuous monitoring, preparation and planning to realize a successful expansion strategy. 


\subsection{Conclusion}

In conclusion, the pharmaceutical environment in China is characterized by perverse market incentives, fragmented regulation and affordability. Nevertheless, being the second largest market by value globally, there presents lots of opportunities to establish a pharmaceutical firm capable of providing drugs profitably. The report has shown that China offers more opportunities than South Africa in expansion of pharmaceutical industry. This is in reflection to the economic, financial, political and cultural analysis. A contractual exporting entry strategy would be preferred as a new establishment is usually lengthy. Entering into a contractual exporting mode will be beneficial as it will allow the mother company continue with its main production without much distraction of new establishment. Upon realizing a large market base, the mother company may set up the new establishment in China to expand both production and marketing of the pharmaceutical products.

\section{References}

Affney, A., Lexchin, J., \& Canadian Pharmaceutical Policy Reform Working Group. (2018). Healing an ailing pharmaceutical system: prescription for reform for United States and Canada. BMJ, 361. https://doi.org/10.1136/bmj.k1039

Best's Country Risk Report, 2018. pp. 1-2.

Brandt, L. and Morrow, P.M., (2017). Tariffs and the Organization of Trade in China. Journal of International Economics, 104, pp.85-103. https://doi.org/10.1016/j.jinteco.2016.10.010

Brink, C.H., (2017). Measuring political risk: risks to foreign investment. Routledge.

Butler, A., (2017). Contemporary South Africa. Macmillan International Higher Education.

David, H., Dorn, D., Hanson, G.H., Pisano, G.P. and Shu, P., (2016). Foreign Competition and Domestic Innovation: Evidence from US Patents.

Eze, M., (2016). Intellectual history in contemporary South Africa. Springer.

Farquhar, J., (2018). Knowing practice: The clinical encounter of Chinese medicine. Routledge.

Fine, B., (2018). The political economy of South Africa: From minerals-energy complex to industrialization. Routledge. https://doi.org/10.4324/9780429496004

Haggard, Stephan, and Robert R. Kaufman. (2018). The political economy of democratic transitions. Princeton University Press. https://doi.org/10.2307/j.ctv39x5bx

Lanteigne, M., 2015. Chinese foreign policy: An introduction. Routledge.

Lu, N., (2018). The dynamics of foreign-policy decision-making in China. Routledge.

Ravenhill, J., (2017). Global political economy. Oxford University Press.

Roux, A., (2016). Everyone's Guide to the South African Economy 12th edition. Penguin Random House South Africa.

World Bank Group (2017). World development indicators 2017. World Bank Publications.

World Trade Organization (2017). International trade statistics. World Trade Organization.

Zweig, D., (2018). Internationalizing China: domestic interests and global linkages. Cornell University Press. 


\subsection{Figures}

\section{Appendices}

CHINA GDP ANNUAL GROWTH RATE

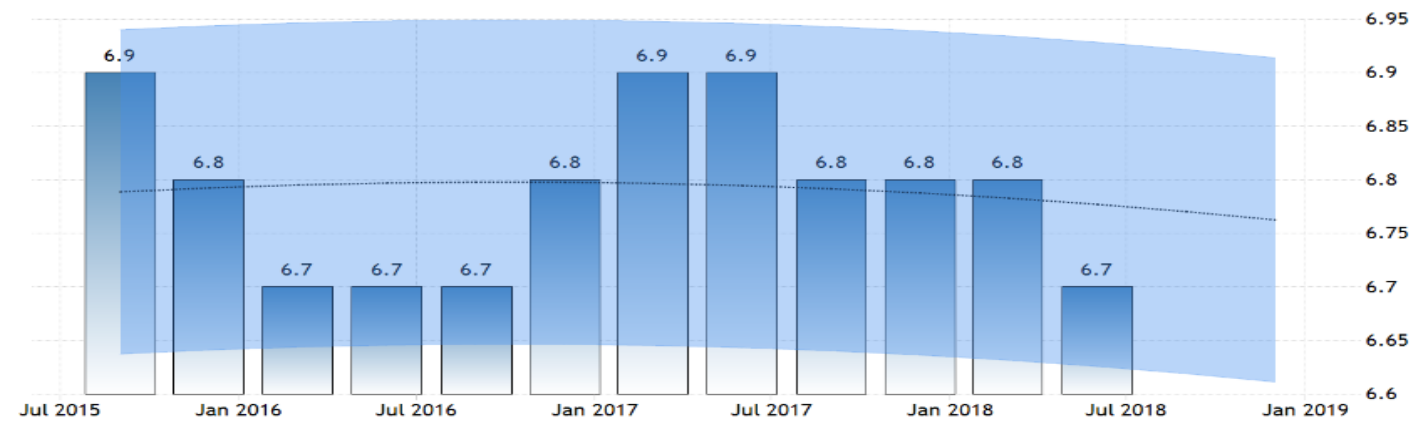

Figure 1: China Growth Rate

(Source: Trading Economics, 2021)

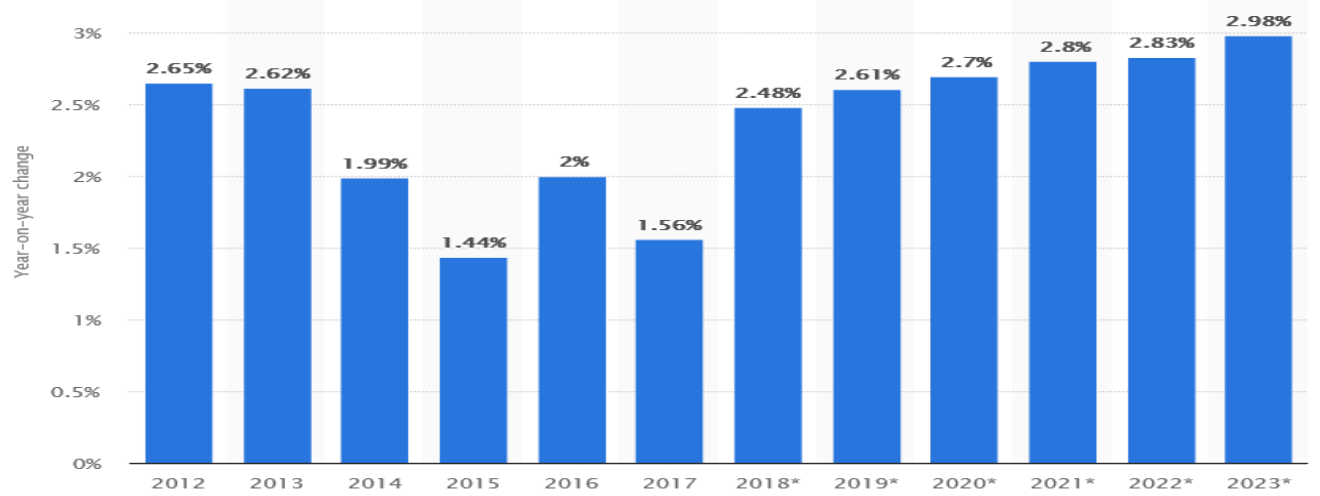

Figure 2: China's Inflation Rate

(Source: The Statistics Portal, 2021)

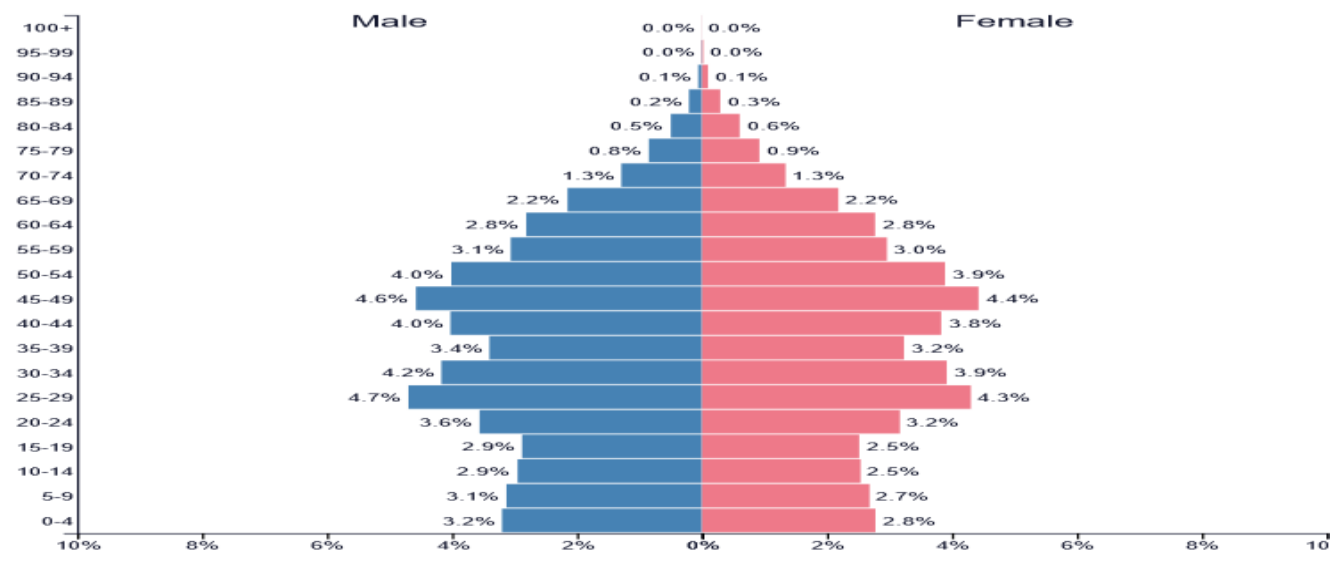

Figure 3: Chinas Population Pyramid

(Source: Population pyramid, 2021) 


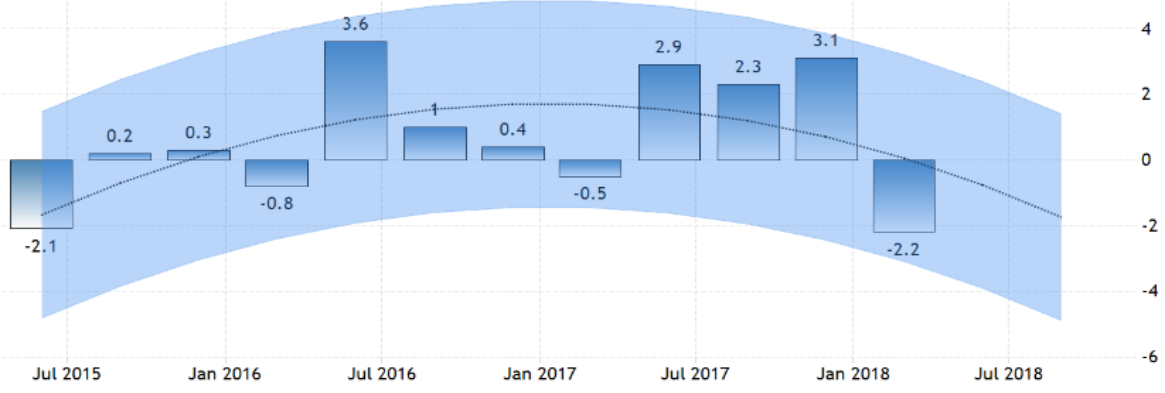

Figure 4: South Africa Growth Rate

(Source: Trading Economics, 2021)

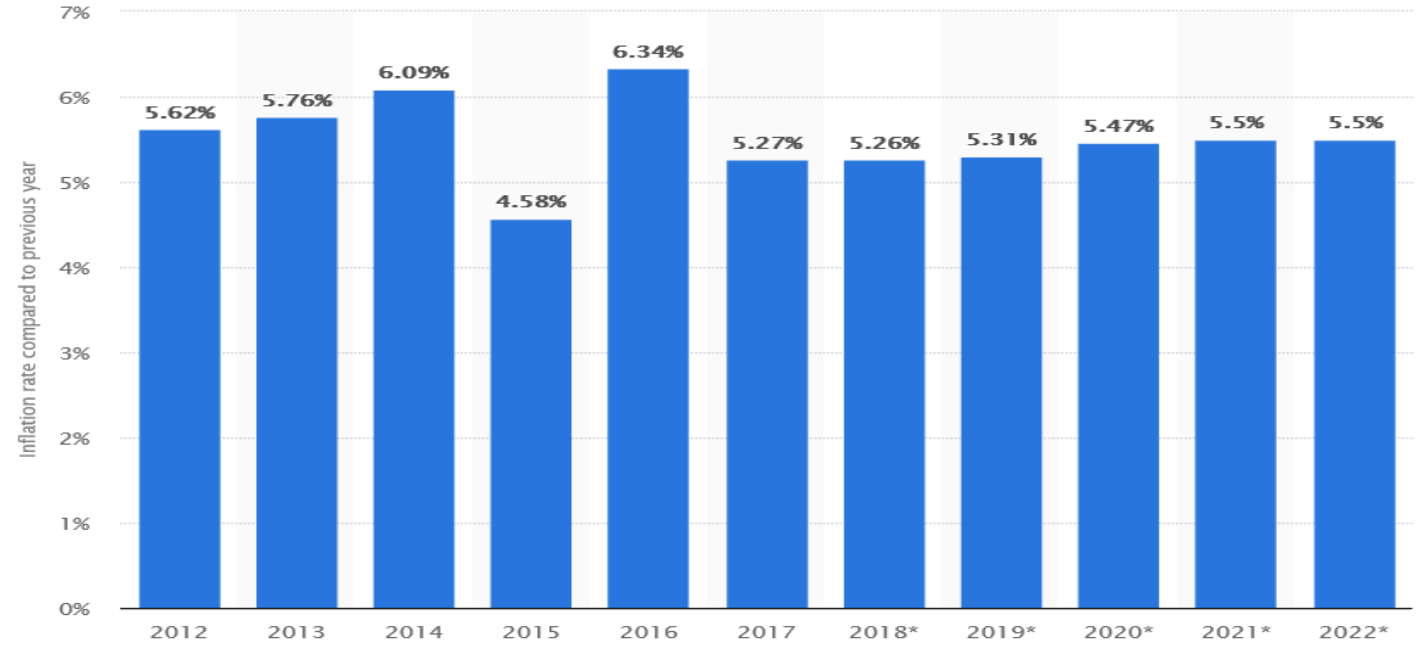

Figure 5: South Africa Inflation Rate

(Source: The Statistics Portal, 2021)

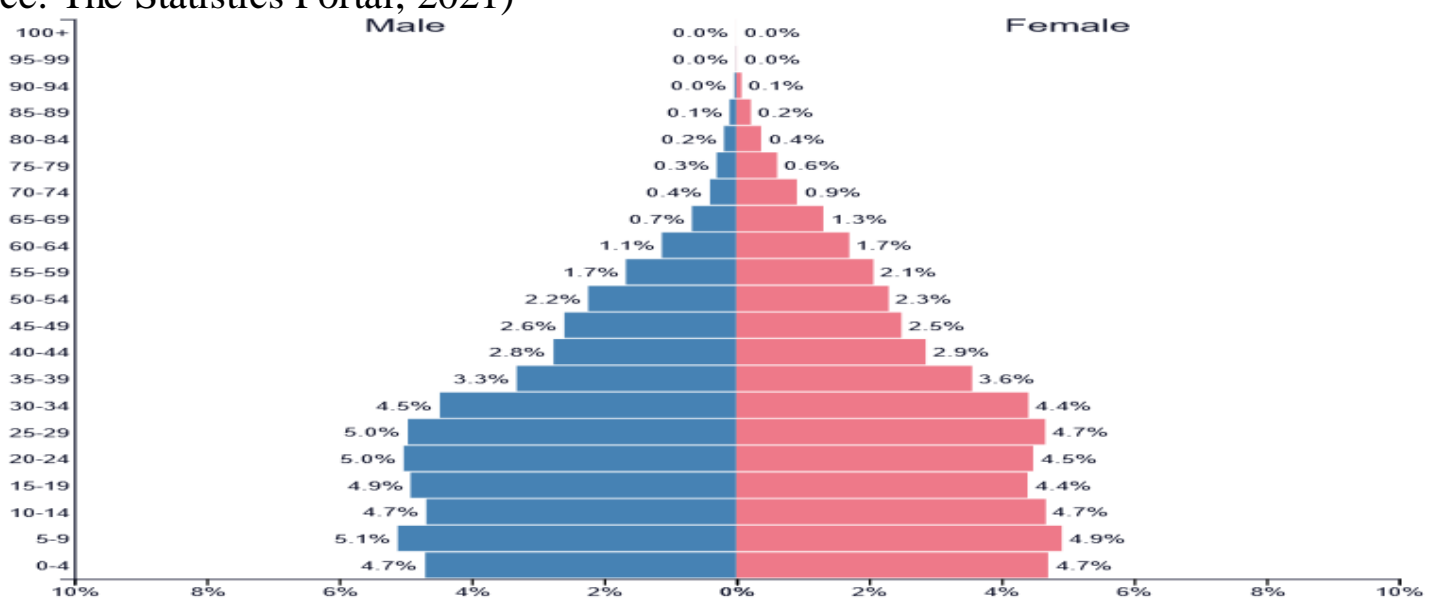

Figure 6: South Africa Population Pyramid

(Source: Population pyramid, 2021) 